\title{
A FUNÇÃO SOCIAL DA EMPRESA: O CAPITALISMO HUMANISTA E A ETICIDADE NA BUSCA DA JUSTIÇA SOCIAL
}

\author{
THE SOCIAL FUNCTION OF THE COMPANY: HUMANIST CAPITALISM AND \\ ETHICS IN THE SEARCH FOR SOCIAL JUSTICE
}

\section{LA FUNCIÓN SOCIAL DE LA EMPRESA: EL CAPITALISMO HUMANISTA Y LA ETICIDAD EN LA BÚSQUEDA POR JUSTICIA SOCIAL}

\begin{abstract}
Carlos Henrique Solimani
Mestrando em Direito pela UNAERP - Universidade de Ribeirão Preto, na área de concentração Concreção dos Direitos Coletivos e Cidadania. Advogado. (Ribeirão Preto, São Paulo, Brasil) http://lattes.cnpq.br/5844634284857114 / http://orcid.org/0000-0002-5149-3314 / chsolimani@hotmail.com
\end{abstract}

AdALBERTO SimÃo FiLHO

Doutor em Direito das Relações Sociais pela Pontifícia Universidade Católica de São Paulo. Professor do Centro Universitário das Faculdades Metropolitanas Unidas, titular da Associação de Ensino de Ribeirão Preto. Professor dos programas de pós-graduação COGEAE/PUC-SP. Advogado. (Ribeirão Preto, São Paulo, Brasil) http://lattes.cnpq.br/7493963807438580 / http://orcid.org/0000-0001-7441-8715 / adalbertosimao@uol.com.br

\begin{abstract}
RESUMO
O presente trabalho tem como objetivo a abordagem da função social da propriedade e da empresa, suas implicações no desenvolvimento econômico, sua utilização como fundamento ao Estado Neoliberal, seu caráter individualista que permitiu a acumulação de riqueza causadora de desigualdade. Na sociedade ocidental pós-moderna, o movimento pela implementação de um Estado Social procura relativizar a natureza jurídica da propriedade concedendo-lhe uma função social de proeminência e procura também impingir ao titular do domínio uma postura positiva em uma proposta de humanização das relações econômicas, para que os indivíduos sejam o fim maior da sociedade capitalista e não mero objeto. Utilizando o método dedutivo, será possível concluir, ao final, que a função social da empresa deve se ater aos desígnios emanados na legislação republicana constitucional brasileira e conceder, através do capitalismo humanista e fraterno, uma vida com dignidade e justiça social.
\end{abstract}

Palavras-chave: Capitalismo Humanista; Dignidade; Empresa Ética; Função Social da Propriedade; Justiça Social.

\section{ABSTRACT}

The present study aims to approach the social function of property and of companies, its implications for economic development, its use as a basis for the Neoliberal State, and its individualistic character that allowed the accumulation of wealth, causing inequality. In postmodern western society, the movement for the implementation of a Social State seeks to relativize the legal nature of property by granting it a social function of prominence and imposing on the holder of the domain a positive posture in a proposal of humanization of economic relations, in order that the people are the greater end of the capitalist society and not a mere object. Using the deductive method, it will be possible to conclude, in the end, that the social function of the company must abide by the aims emanating from the Brazilian constitutional republican legislation and grant, through humanistic and fraternal capitalism, a life with dignity and social justice.

Keywords: Humanist Capitalism; Dignity; Ethical company; Social Function of Property; Social Justice. 


\section{RESUMEN}

El presente trabajo tiene como objetivo el abordaje de la función social de la propiedad y de la empresa, sus implicaciones en el desarrollo económico, su uso como base para el Estado neoliberal y su carácter individualista que permitió la acumulación de riqueza causando desigualdad. En la sociedad occidental posmoderna, el movimiento hacia la implementación de un estado social busca relativizar la naturaleza jurídica de la propiedad, concediéndole una función social de prominencia e imponiendo al titular del dominio una postura positiva en una propuesta de humanización de las relaciones económicas para que los individuos sean el fin mayor de la sociedad capitalista y no un mero objeto. Con el método deductivo, será posible concluir, al final, que la función social de la empresa debe respetar los objetivos que emanan de la legislación republicana constitucional brasileña y conceder, a través del capitalismo humanista y fraterno, una vida con dignidad y justicia social.

Palabras clave: El capitalismo humanista; Dignidad; Empresa Ética; Función Social de la Propiedad; Justicia Social.

\section{SUMÁRIO}

INTRODUÇÃO; 1 A PROPRIEDADE - DO ESTADO LIBERAL AO ESTADO SOCIAL; 2 A TEORIA DO CAPITALISMO HUMANISTA; 2.1 Conceito - Dimensionamento - Globalização; 3 A FUNÇÃO SOCIAL DA EMPRESA; 3.1 Previsão Legal; 3.2 Objetivos da Função Social da Empresa; CONCLUSÃO; REFERÊNCIAS.

\section{INTRODUÇÃO}

O desenvolvimento econômico e social de um país é de fundamental importância para que seus indivíduos usufruam de uma dignidade plena, porém tais circunstâncias são diretamente afetadas pela conjunção de estruturas econômicas e jurídicas que fazem parte do cotidiano empresarial, laboral e social. A Globalização, assim como as políticas públicas implementadas pelo Estado, influencia esse cenário, sendo necessário consignar que a concentração de riqueza e renda conduz a mazelas sociais experimentadas pela classe mais desfavorecida da população e pelos trabalhadores, os quais não possuem efetivo poder de barganha nessa conturbada relação entre capital e trabalho.

A política capitalista neoliberal - exportada pelos países ricos e grandes conglomerados globais ao longo da história, foi incorporada pelos países pobres e por aqueles em desenvolvimento (dentre eles o Brasil) -, de um lado foi responsável por transformações tecnológicas, por avanços científicos nas mais diversas áreas, porém, por outro lado, não foi capaz suficientemente de garantir uma vida digna e de conceder a plena cidadania. 0 capitalismo global sopra ventos de desigualdade ao sabor do constante desequilíbrio econômico, ecoando sofrimento, desemprego, aflição, doenças, fome, mortes e desabrigo em todos os continentes.

“De fato, para a maior parte da humanidade a globalização está se impondo como uma fábrica de perversidades. O desemprego crescente torna-se crônico. A pobreza aumenta e as 
classes médias perdem em qualidade de vida. O salário médio tende a baixar”1. Neste cenário, torna-se obrigação do Estado Social adotar medidas que preservem a pessoa humana por meio de sua valorização e proteção como centro do direcionamento das políticas públicas, contudo esta tarefa engrandecedora deve ser realizada sem qualquer interferência ideológica. O Brasil e os demais países da América Latina tendem a entremear questões de natureza social e econômica, cidadania e bem-estar social com política ideológica tão comum no século XX, garantida pela dicotomia entre capitalismo, socialismo e comunismo. As necessidades humanas não são satisfeitas pelos resultados de lutas ideológicas, principalmente por aquelas iniciativas dissimuladas em que propostas socialmente relevantes escondem, em verdade, iniciativas de dominação política de um determinado grupo.

A população desguarnecida de políticas públicas de criação, manutenção e preservação da cidadania, necessita dos benefícios oriundos do investimento em saúde, que conduza a uma existência digna; de educação que promova o conhecimento isento de influências doutrinárias e que traga condições para que o indivíduo seja capaz de contribuir para o desenvolvimento da ciência, da tecnologia, da própria educação; de emprego digno que conduza o cidadão a uma independência que o possibilite trilhar o caminho de sua livre escolha em condições de sustentar a si e sua família; enfim, do que seja necessário para uma existência digna.

Entrementes, na perspectiva do capitalismo neoliberal, o homem é mero instrumento, um meio para se conseguir o tão almejado lucro, fim maior das atividades empresariais. 0 artigo 170 da Constituição Federal contém vários princípios da ordem econômica que contemplam, dentre outros, a função social da propriedade, tendo a função social da empresa como corolário da justiça social, “já que a função social da empresa é um conceito que foi consolidado não apenas para impedir o exercício antissocial da atividade empresarial, mas para direcioná-la ao atendimento das finalidades sociais, inclusive mediante imposição de deveres à empresa" 2 .

Não obstante a previsão constitucional e infraconstitucional da função social da propriedade, conforme preconiza o artigo 170 da Constituição Federal e $\S$ único do artigo 2.035 do Código Civil, a construção de uma nova empresarialidade, com valores éticos e morais aplicados ao exercício da atividade mercantil, tem se mostrado distante da realidade, haja vista os acontecimentos políticos e econômicos hodiernos, mormente os deflagrados na conhecida operação "Lava Jato". Este cenário revelou de modo efetivo o desvio da finalidade social do uso

\footnotetext{
${ }^{1}$ SANTOS, Milton. Por uma outra globalização. Rio de Janeiro: BestBolso, 2011. p. 13.

${ }^{2}$ LOPES, Ana Frazão de Azevedo. Empresa e propriedade - função social e abuso de poder econômico. São Paulo: Quartier Latin, 2006. p. 280.
} 
da propriedade, já que a prática empresarial mostra-se circunscrita à mera obtenção de lucro a qualquer preço, com desprezo do interesse social, o que se faz por meio de condutas ilícitas como a utilização do trabalho escravo, do Dumping Social; do assédio moral, da sonegação de direitos trabalhistas, sonegação de tributos, corrupção, dentre outros.

A questão a ser tratada e referenciada no presente artigo tem como objetivo a abordagem da função social da propriedade e da empresa, suas implicações no desenvolvimento econômico, sua utilização como fundamento ao Estado Neoliberal, seu caráter individualista que permitiu a acumulação de riquezas causadora de desigualdades, bem como a forma de defesa contra o abuso do poder econômico que se instala na sociedade em linha contrária à função social da propriedade.

Pretende-se responder algumas indagações acerca da possibilidade de se impelir o titular do domínio dos meios de produção a adotar posturas positivas no uso da propriedade com vistas à efetivação da teoria da função social da empresa; será objeto de perquirição se a função social da empresa poderá ser melhor harmonizada com a implantação da teoria do capitalismo humanista como forma de proteção dos direitos fundamentais da pessoa humana.

O artigo foi desenvolvido por meio de revisão da literatura através do método hipotético-dedutivo, com levantamento dos aspectos doutrinários sobre o tema proposto, através de pesquisa bibliográfica, buscando-se perquirir, a partir das premissas da função social da empresa e da propriedade como hipótese em análise, se a empresa deve atuar isoladamente e desvinculada de suas responsabilidades sociais com seus empregados, fornecedores, consumidores, com a comunidade onde está inserida e com o meio ambiente em que se instalou, procurando apenas satisfazer seus interesses na busca do lucro, sob quaisquer circunstâncias.

Inicialmente será tratada a propriedade, sua raiz histórica, a função social desde o estado liberal até o estado social e sua definição conceitual. Em seguida será objeto de avaliação a teoria do capitalismo humanista, seu conceito, seu dimensionamento como forma de relativização do capitalismo neoliberal contemporâneo, a Globalização e sua influência no mundo atual. Por fim, será tratada a função social da empresa, sua previsão legal, os objetivos e sua finalidade fundamental como forma de condicionar a atividade empresarial à realização da justiça social no sentido de haver coincidência entre os objetivos sociais e empresariais com os objetivos sociais traçados pelo regime democrático e republicano brasileiro, com a necessária distribuição da riqueza e dos benefícios da atividade econômica com o fim de proporcionar aos cidadãos uma vida digna, procurando obter respostas aos questionamentos acima. 


\section{A PROPRIEDADE - DO ESTADO LIBERAL AO ESTADO SOCIAL}

De início, imperioso destacar que a função social da propriedade, tal qual prevista hodiernamente, "da qual decorre a função social da empresa, vem suscitando grandes controvérsias, especialmente no que se refere à sua implementação como cláusula geral orientadora do exercício da propriedade privada e da atividade empresarial”3.

A empresa como atividade econômica organizada, que visa a produção ou a circulação de bens ou serviços, nos moldes definidos a partir do Art. 982 c/c. Art. 966 do Código Civil, será o objeto específico de nossa análise, partindo-se da premissa de que a empresarialidade não está ligada conceitualmente à busca de lucro como resultado finalista, mas sim ao exercício desta atividade econômica como forma de obtenção de resultados partilháveis entre sócios. Segundo Simão Filho ${ }^{4}$, o fato de a atividade ter natureza econômica, deve contribuir para a eficiência de seus meios de produção e de organização, para que se possa atingir estes resultados em que o lucro esperado será o mais importante destes. Todavia, a aplicação do instituto da finalidade social da empresa nesse contexto contribui para que o lucro financeiro contábil, apesar de importante, não seja o único objetivo empresarial.

Impende observar, no contexto de empresa, enquanto organização que exerce uma atividade econômica, tendo como objeto a produção e a circulação de bens e serviços com intuito de lucro, que sua importância histórica como fenômeno socioeconômico é da mais alta relevância. Isto tendo em vista sua posição estrategicamente lançada no centro da economia contemporânea, cujo desenvolvimento notabiliza-se a partir da Revolução Industrial até atingir seu patamar atual de produção massificada, pressupondo de modo evidente uma organização complexa que se utiliza de inúmeros elementos na concretização de sua finalidade produtiva como matéria-prima, força de trabalho e capital, interação esta que resultará na concretização de riqueza. ${ }^{5}$ Para a consecução de seus objetivos sociais, com vistas a uma atividade criadora de riqueza, o empresário se utiliza de um complexo de bens, dentre eles o estabelecimento comercial e a somatória de itens que compõem sua propriedade e domínio.

\footnotetext{
${ }^{3}$ LOPES, Ana Frazão de Azevedo. Empresa e propriedade - função social e abuso de poder econômico. São Paulo: Quartier Latin, 2006. p. 21.

${ }^{4}$ SIMÃO FILHO, Adalberto. Direito Societário Contemporâneo. In: BIANCHINI, Aline; GOMES, Luiz Flávio (Coord.). Direito Empresarial III. São Paulo: Saraiva, 2012. v. 28. p. 34.

${ }^{5}$ ARDUIN, Ana Lúcia Alves da Costa. A teoria Jurídica da empresa. In: COELHO, Fábio Ulhoa (Coord.). Tratado de Direito Comercial. São Paulo: Saraiva, 2015. v. 1. p. 74.
} 
A outro lado, a raiz histórica do instituto da propriedade remonta ao Direito Romano, de natureza individual, em cuja época era mesclada de determinações políticas, em que apenas o cidadão romano poderia adquirir a propriedade de solo respectivamente romano. Esse direito posteriormente se estendeu aos estrangeiros por meio do iuscomercii, consolidando-se a codificação por meio de Justiniano, no Corpus luris Civilis, resultado de uma lenta evolução que do Direito Romano se estenderia por mais mil anos ${ }^{6}$. Nos dias atuais, a propriedade individual não conserva os atributos de forma idêntica aos de suas origens históricas, apesar de reconhecer "o dominus o poder sobre a coisa, é exato que o domínio enfeixa os mesmos atributos originários - iusutendi, fruendi et abutendi"7. De acordo com Caio Mário da Silva Teixeira,

[...] é inegável também que essas faculdades suportam evidentes restrições legais, tão frequentes e severas, que se vislumbra a criação de novas noções. São restrições e limitações tendentes a coibir abusos e tendo em vista impedir que o exercício do direito de propriedade se transforme em instrumento de dominação. Tal tendência ora se diz "humanização" da propriedade, ora se considera filiada a uma corrente mais ampla com o nome de "paternalismo" do direito moderno (Colin et. Capitant), ora se entende informada a nova noção pelos princípios do "relativismo" do direito (Josserand). ${ }^{8}$

Em consonância do entendimento de Caio Mário, de que a propriedade não pode se transformar num instrumento de dominação, e na esteira da definição romanística de Maria Helena Diniz, sobreleva dizer que "a propriedade é o direito que a pessoa física ou jurídica tem, dentro dos limites normativos, de usar, gozar e dispor de um bem, corpóreo ou incorpóreo, bem como de reivindicar de quem injustamente o detenha"', observando-se, assim, que as limitações impostas pela lei são de caráter inalienável para o Estado de Direito.

Esse caráter individualista, nascido no seio do direito romano, passou por alterações na forma como a relação homem objeto ocorria, sendo que, na idade média, essa condição foi marcada pela existência de uma dualidade, a do proprietário e a do vassalo que a explorava economicamente sob o jugo do senhor. Evidentemente que a evolução do direito de propriedade teve íntima relação com a forma de desenvolvimento do Estado e sua relação com o indivíduo, cuja formação ocupou pelo menos três séculos na história da Europa. ${ }^{10}$

\footnotetext{
${ }^{6}$ PEREIRA, Caio Mário da Silva. Instituições de Direito Civil. Rio de Janeiro: Forense, 1990. p. 65.

${ }^{7}$ PEREIRA, Caio Mário da Silva. Instituições de Direito Civil. Rio de Janeiro: Forense, 1990. p. 67.

${ }^{8}$ PEREIRA, Caio Mário da Silva. Instituições de Direito Civil. Rio de Janeiro: Forense, 1990. p. 67.

${ }^{9}$ DINIZ, Maria Helena. Código Civil Anotado. 6. ed. São Paulo: Saraiva, 2000. p. 444.

${ }^{10}$ PADILHA, Norma Sueli; VECHIA, Rosangela. Direito de propriedade e função social da propriedade: os desafios propostos pelo estatuto da cidade. [200-?] Disponível em:
} 
O pensamento político clássico vai acompanhar esse processo de formação a partir do século XV, com Maquiavel até consolidar-se nas obras de Hobbes, Locke e Rousseau, autores cuja ideia central é a do Contrato Social que funda o Estado. Para sobreviver às ameaças da natureza, o homem primitivo busca viver em sociedade. Na vida em sociedade surgem os conflitos de interesses e o homem abre mão da liberdade que tinha em "estado de natureza" e cria por "contrato" o Estado. A finalidade é de garantir e proteger o direito à vida e à propriedade. Do povo emana todo o poder do Estado, e é a serviço dos interesses coletivos desse povo que o Estado deve agir.

[...]

As profundas transformações na Europa acompanham o declínio do modo de produção feudal e sua progressiva substituição pelo modo de produção capitalista. $\mathrm{O}$ crescimento do comércio fez nascer uma nova classe formada por ricos comerciantes - a burguesia. As Reformas protestantes confrontam o poder e a hegemonia da Igreja e do Papa. O feudalismo agoniza. As grandes navegações, o mercantilismo, a acumulação de riqueza na Europa cria as condições históricas para o desenvolvimento do novo modo de produção. 0 trabalho artesanal vai sendo, progressivamente, substituído pelo trabalho dividido. 0 artesão se transforma em assalariado. A burguesia, agora dona dos meios de produção, alcança poder econômico e, confronta as estruturas do "velho regime". O capitalismo nascente transforma a vida em sociedade e demanda novas formas de organização do Estado. ${ }^{11}$

Importante realçar a evolução do Estado e da sociedade neste período, embora “houvesse traços do individualismo desde a tradição judaico-cristã, somente a partir da Reforma e da luta pela tolerância religiosa, bem como do jusnaturalismo dos séculos XVII e XVIII, aperfeiçoou-se o modelo individualista que influenciou, de forma direta, o Estado Liberal"12. Neste sentido, o jusnaturalismo representou o rompimento da antiga ideia de que o homem seria um ser essencialmente social para o entendimento de que o indivíduo basta por si mesmo, surgindo a aceitação "de que eram as vontades individuais coordenadas por meio de um contrato social, que justificavam a formação e a legitimidade do Estado"13, culminando com "a ideia dos

<http://www.publicadireito.com.br/conpedi/manaus/arquivos/anais/campos/rosangela_vecchia.pdf >. Acesso em: 14 out. 2016. p. 2.

${ }_{11}$ PADILHA, Norma Sueli; VECHIA, Rosangela. Direito de propriedade e função social da propriedade: os desafios propostos pelo estatuto da cidade. [200-?] Disponível em:

<http://www.publicadireito.com.br/conpedi/manaus/arquivos/anais/campos/rosangela_vecchia.pdf >. Acesso em: 14 out. 2016. p. 3.

12 LOPES, Ana Frazão de Azevedo. Empresa e propriedade - função social e abuso de poder econômico. São Paulo: Quartier Latin, 2006. p. 30.

${ }^{13}$ LOPES, Ana Frazão de Azevedo. Empresa e propriedade - função social e abuso de poder econômico. São Paulo: Quartier Latin, 2006. p. 30. 
direitos subjetivos relacionados à liberdade e à propriedade, como desdobramentos naturais da condição humana"14.

Para Ana Frazão de Azevedo Lopes, o individualismo de Hobbes decorre da ideia do auto interesse e de que o homem não era naturalmente inclinado a amar os outros homens, ao contrário, o estado de natureza em que se encontrava o homem o colocava em estado de guerra constante, justificando que a única forma de estabelecer o convívio pacífico era por meio do contrato social, que foi igualmente adotado por Locke. ${ }^{15}$

Thomas Hobbes inaugura o pensamento jusnaturalista e contratualista de formação do Estado Moderno quando identifica o sentido das forças que emanam do indivíduo para constituir o Estado. Em sua obra clássica "O Leviatã" de 1651, Hobbes consolida sua posição histórica de grande teórico da soberania do Estado. [...]

Dos autores clássicos da ciência política, Locke é quem delimita com precisão a propriedade na visão liberal, base sobre a qual o Estado Moderno irá fundar-se. Os homens em "estado de natureza" vivem livres, iguais e independentes. Livres, porém, submetidos às leis da natureza, isto é, à razão. Cada um é livre para dispor de seu corpo; não se deve abusar dessa liberdade para prejudicar os demais; não é preciso atentar contra outros, tudo na natureza é abundante.

Amplo é o conceito de propriedade em Locke, '[...] o homem, sendo senhor de si próprio e proprietário de sua pessoa e das ações ou do trabalho que executa, teria ainda em si mesmo a base da propriedade'. (MELLO, apud WEFFORT, 2000, p. 86). A propriedade em Locke já existe no 'estado de natureza'. A terra dada por Deus em comum a todos os homens pode dela se tornar proprietário à medida que incorporar a ela o seu trabalho. Pelo trabalho o homem torna-se proprietário privado da terra, estabelecendo sobre o bem um direito 'próprio' e 'oponível' aos outros homens. ' $O$ trabalho era, pois, na concepção de Locke, o fundamento originário da propriedade'. ${ }^{16}$

Locke contribuiu sensivelmente para a criação do Estado de direito e, por consequência, para o Estado Liberal, mas não apenas em razão do simples reconhecimento da existência dos direitos individuais naturais, mas também de sua supremacia sobre o poder político e sobre qualquer outro poder. No Estado liberal, o limite do poder estatal estava calcado no reconhecimento dos direitos fundamentais do cidadão, tendo a liberdade e propriedade como valores absolutos, porém esta proposta não se mostrou sustentável no decorrer do tempo, em

\footnotetext{
${ }^{14}$ LOPES, Ana Frazão de Azevedo. Empresa e propriedade - função social e abuso de poder econômico. São Paulo: Quartier Latin, 2006. p. 30.

${ }^{15}$ LOPES, Ana Frazão de Azevedo. Empresa e propriedade - função social e abuso de poder econômico. São Paulo: Quartier Latin, 2006. p. 32.

${ }_{16}$ PADILHA, Norma Sueli; VECHIA, Rosangela. Direito de propriedade e função social da propriedade: os desafios propostos pelo estatuto da cidade. [200-?] Disponível em: <http://www.publicadireito.com.br/conpedi/manaus/arquivos/anais/campos/rosangela_vecchia.pdf >. Acesso em: 14 out. 2016. p. 6.
} 
face do incremento da complexidade social e da necessidade pujante de se impor limitações pelo Estado em prol do bem comum. ${ }^{17}$

A proposta liberal, especialmente na versão que lhes deram Locke e Kant, priorizava a importância da propriedade e da liberdade como direitos naturais básicos e fundamentais, partindo do princípio de que o reconhecimento formal destes direitos seria suficiente para assegurar a harmonia social. Havia, em todas as variáveis liberais do contrato social, tais como em Locke e em Kant, a ideia de que este, para garantir a liberdade, não precisaria de outra coisa senão de estar expressamente reconhecido em termos de direito formal $(. . .)^{18}$

Para Rousseau, a proteção da pessoa e de seus bens era a questão fundamental para o contrato social:

'Encontrar uma força de associação que defenda e proteja de toda a força comum a pessoa e os bens de cada associado, e pela qual, cada um, unindo-se a todos, não obedeça, portanto, se não a si mesmo, e permaneça tão livre como anteriormente'. Tal é o problema fundamental cuja solução é dada pelo contrato social. ${ }^{19}$

Como mencionado alhures, o Estado liberal passou a dar espaço ao denominado Estado Social que surgiu da necessidade de se dar maior amplitude à diminuição das desigualdades sociais e a necessidade de se dar garantia tanto aos direitos individuais quanto aos direitos sociais, cabendo ao Estado desempenhar papel importante nesta tarefa por meio da intervenção nos meios econômicos, regulando de forma mais justa as relações, de modo a trazer equilíbrio neste processo de desenvolvimento das relações humanas.

Entende-se por Estado Social a ordem político-jurídica moderna fundada na proteção social e na segurança econômica garantida pela intervenção do Estado nos limites da democracia e do Estado de Direito. Juridicamente se manifesta pela constitucionalização de direitos de natureza social, de responsabilidade do Estado, garantidos efetivamente pela forte intervenção estatal na economia. A presença do Estado na economia, que foi o grande debate do século XX, evoluiu para um capitalismo de Estado forte, fundado no Keynesianismo. ${ }^{20}$

\footnotetext{
17 LOPES, Ana Frazão de Azevedo. Empresa e propriedade - função social e abuso de poder econômico. São Paulo: Quartier Latin, 2006. p. 32, 80.

${ }^{18}$ LOPES, Ana Frazão de Azevedo. Empresa e propriedade - função social e abuso de poder econômico. São Paulo: Quartier Latin, 2006. p. 34.

${ }_{19}$ ROUSSEAU, Jean-Jacques. Do Contrato Social ou Princípios do Direito Político. Tradução de Lourdes Santos Machado. São Paulo: Nova Cultural, 1999. p. 69.

${ }_{20}$ ROCHA, Manoel Ilson Cordeiro. A crise do Estado Social na Europa Ocidental e na América Latina contemporânea e a precarização dos direitos fundamentais sociais: um estudo a partir das referências brasileiras e portuguesas. Revista da Fundação Educacional de Ituverava, Nucleus, Ituverava, v. 13, n. 1, p. 319-325, 2016. Disponível em:
} 
Conforme será visto à frente, o desenvolvimento do Estado Social abriu espaço para o pensamento filosófico e jurídico da questão da solidariedade social, da qual desenvolveu-se a teoria da função social da propriedade, tendo como desdobramentos, na contemporaneidade, a teoria da função social da empresa.

\section{A TEORIA DO CAPITALISMO HUMANISTA}

\subsection{Conceito - Dimensionamento - Globalização}

Antes de adentramos à questão relacionada à função social da empresa, necessário se faz trazer à discussão algum lineamento acerca do que se convencionou denominar de capitalismo humanista como forma de relativização do capitalismo neoliberal contemporâneo.

A sociedade ocidental vem sendo submetida às consequências da modernização desde a revolução industrial, com embates multifacetários entre o capital e o trabalho na tentativa de equilibrar a sistemática de exploração da força de trabalho pelo capital, com a garantia mínima de subjacência dos indivíduos a uma vida digna. Esse desafio transformador, por óbvio, permeia a relação capital e trabalho. Além disso, a luta por melhor qualidade de vida avança pelos caminhos da criação de normas protetivas e alcança o Estado como meio garantidor do mínimo existencial.

A proeminência da força acumulativa do capital em detrimento da força de trabalho, que quase nada acumula, desafia os meios institucionais em perquirir uma justa distribuição de renda. De um lado o capitalista e seu afã incontido pela acumulação de riquezas e, de outro, a sociedade contrapondo sua força (desproporcional), de resistir a ser definhada pelo capital. 0 resultado do embate é uma flagrante desigualdade social que se propaga aos quatro cantos do planeta, tendo o Brasil como um dos mais respeitáveis representantes dessa contraproducente desigualdade.

A riqueza, representada pelo acúmulo monetário e pelo patrimônio não financeiro, é fonte de poder. 0 detentor de patrimônio, financeiro ou não, em grande quantidade, tem sob seu controle a condução e a manutenção do destino, de alguém ou de alguma coisa, a que se propõe o capital. Por dedução, se há acúmulo de riqueza por um lado, de outro haverá pobreza

<http://www.nucleus.feituverava.com.br/index.php/nucleus/article/view/1468/2019>. Acesso em: 17 out. 2016. 
e dependência, uma das causas evidentes da desigualdade social. A acumulação de um determinado bem ou de vários bens é causa de escassez e de sua supervalorização, consequência econômica da oferta e procura. Baixa oferta conduz a alta valorização, seja de bens ou de moeda. Receita básica de economia de mercado. A política da escassez é medida perversa mantida pelo capitalismo numa complexa estratégia de medida do maior lucro.

A acumulação de riqueza sem critérios objetivos e técnicos tem levado a uma grande desigualdade social. A globalização é considerada como o apogeu do processo de internacionalização do mundo capitalista e o resultado de ações emergenciais de um mercado global responsável por medidas essenciais dos processos políticos atualmente eficazes, tendo como meio propulsor unificado a mais-valia universal ${ }^{21}$. Milton Santos, analisando o intenso sistema globalizado, assenta que:

Esse motor único se tornou possível porque nos encontramos em um novo patamar da internacionalização, como uma verdadeira mundialização do produto, do dinheiro, do crédito, da dívida, do consumo, da informação. Esse conjunto de mundializações, uma sustentando e arrastando a outra, impondo-se mutuamente, é também um fato novo.

[...]

A atual competitividade entre as empresas é uma forma de exercício dessa maisvalia universal, que se torna fugidia exatamente porque deixamos o mundo da competição e entramos no mundo da competitividade. 0 exercício da competitividade torna exponencial a briga entre as empresas e as conduz a alimentar uma demanda diuturna de mais ciência, de mais tecnologia, de melhor organização, para manter-se à frente da corrida.

Quando, na universalidade, somos solicitados todos os dias a trabalhar para melhorar a produtividade como se fosse algo abstrato e individual, estamos sendo impelidos a oferecer às grandes empresas possibilidades ainda maiores de aumentar sua mais-valia.

[...]

Se ela pode parecer abstrata, a mais valia agora universal se impõe como um dado empírico, objetivo, quando utilizada no processo da produção e como resultado da competitividade. ${ }^{22}$

A globalização impôs ao mundo uma nova forma de vida acompanhada de mudanças de paradigma. Empresas se tornaram globais, a produção se dividiu em etapas regionais, com plantas espalhadas por diversos países, cada titular da fabricação de uma parcela do produto final, detendo cada qual a respectiva parcela de informação tecnológica. Essa forma de produção permite adequar os interesses empresariais facilitando a transferência de sua planta

\footnotetext{
${ }^{21}$ SANTOS, Milton. Por uma outra globalização. Rio de Janeiro: BestBolso, 2011. p. 15.

${ }^{22}$ SANTOS, Milton. Por uma outra globalização. Rio de Janeiro: BestBolso, 2011. p. 20-21.
} 
para outros países ao sabor da lucratividade e facilidades obtidas no processo de negociação das instalações.

$\mathrm{Na}$ facilidade com que as empresas mudam suas plataformas industriais, levam consigo, do mesmo modo, os empregos, a renda, as divisas internacionais, deixando para trás as consequências negativas dessa troca. Se atualmente não existem dificuldades operacionais para alteração da localização das plantas industriais, pior ainda para outras dimensões produtivas do capitalismo, como ocorre no setor financeiro, atividade financeira mundial evoluiu de US\$ 18 bilhões de dólares no início dos anos 70 para US\$ 150 bilhões em 1987, passando de US\$ 860 bilhões em 1992 para US\$ 1,230 trilhão em 1995²3. Trata-se de grande volume financeiro transferido diariamente de mercado em mercado, com o único objetivo de incrementar o acúmulo de riquezas.

Os países ricos em geral são detentores de processos produtivos que agregam alta tecnologia em produtos e serviços, os quais não são transferidos aos países que recebem as plantas industriais. A existência de plantas industriais, a exemplo da Apple, IBM e Microsoft, em países como a Taiwan, China e Coréia do Sul, não significa que a tecnologia existente no processo produtivo ou no produto final seja transferida. Esta é a forma usual de produção no mundo globalizado contemporâneo, empresas de alta tecnologia desenvolvem seus produtos nas suas sedes, evidentemente localizadas em países ricos, mas transferem a produção, por depender de mão de obra barata, a países pobres, que não retém a parcela deste conhecimento. Produtos como o iPod, iPhone e iPad são desenvolvidos pela Apple na sua base de pesquisa e desenvolvimento na Califórnia e produzidos onde a mão de obra é mais barata, no caso na China pela taiwanesa Foxconn. ${ }^{24}$

A globalização, ao invés de ser uma porta aberta ao desenvolvimento, acaba por ser apontada como uma das causas da desigualdade. Diogo R. Coutinho ${ }^{25}$, sobre o tema desigualdade e desenvolvimento, esclarece que são vários os fatores que levam à desigualdade, e a globalização é um deles, havendo ainda outros que acirrariam a desigualdade como a existência de subsídios e políticas protecionistas dos países ricos, assimetrias comerciais mundiais sem regulamentação da OMC e deterioração do equilíbrio comercial entre países industrializados, que

${ }^{23}$ DALCERO, Pedro Luiz. Globalização financeira e volatilidade de capitais: a busca de uma alternativa racionalista. Rev. bras. polít. int., Brasília, v. 40, n. 2, p. 131-143, dez. 1997. Disponível em: <http:// www.scielo.br/scielo.php?script=sci_arttext\&pid=S0034-73291997000200006\&lng=en\&nrm=iso>. Acesso em: 3 set. 2017.

${ }^{24}$ MAZZUCATO, Mariana. O estado empreendedor: desmascarando o mito do setor público vs. setor privado. Tradução de Elvira Serapicos. São Paulo: Portfólio-Penguin, 2014. p. 233.

${ }^{25}$ COUTINHO, Diogo R. Direito, desigualdade e desenvolvimento. São Paulo: Saraiva, 2013. p. 56. 
trocam produtos de alto valor agregado por commodities agrícolas de baixa densidade tecnológica. ${ }^{26}$

Coutinho, ao analisar as causas da desigualdade, elenca vários fatores, dentre eles a globalização, mas também outros, como o mercado de trabalho, o acesso à educação, questões relacionadas ao gênero, raça e cultura e, por fim, a forma como os países se desenvolveram após atravessarem os processos de colonização, modernização, industrialização, inovação, inserção internacional, entre outros fatores. No entanto, as causas da desigualdade não podem, a nosso ver, serem avaliadas de forma isolada, pois todas as causas mencionadas estão fortemente interrelacionadas e intrinsecamente provocam resultados em face da forma como cada uma das causas ou fatores se realimentam. É um intrincado processo de alimentação e realimentação, em que a globalização potencializa de modo exponencial as consequências boas e ruins aos atores globais. $^{27}$

Para Coutinho, o mercado de trabalho é uma das principais causas da desigualdade, podendo ser explicada em economias de mercado como resultado da interação de curvas de oferta e demanda por postos de trabalho. E continua:

\begin{abstract}
Em uma de suas tensões mais fundamentais, o capitalismo encerra um conflito no qual capitalistas e empresários procuram manter salários baixos e, de outro lado, sindicatos de trabalhadores e outras formas de agregação de interesses de trabalhadores apresentam suas demandas e pleitos de apropriação de parcelas do rendimento do trabalho. Como é sabido, a disputa por um posto de trabalho por muitos candidatos tende a reduzir a remuneração oferecida por aquele trabalho, uma vez que a oferta de mão de obra supera significativamente a demanda. Assim, a competição entre trabalhadores tendencialmente reduz a quantidade de renda que os empregadores estão dispostos a transferir sob a forma de salários e o crescimento populacional - fenômeno em geral associado a países em desenvolvimento, não a países desenvolvidos - tende a aumentar a oferta da força de trabalho, o que deprime ainda mais os salários, especialmente se se levar em conta os ganhos de produtividade por trabalhador. ${ }^{28}$
\end{abstract}

A oferta e procura, evidentemente, é causadora de volatilidade nos preços dos salários, contudo a curva de oferta e demanda dos postos de trabalho sofre diretamente a influência que a globalização impõe ao mercado interno de cada país. No mundo contemporâneo, não é possível dissociar a interação global dos mercados. O desemprego no Brasil é resultado de políticas públicas internas, mas também é influenciável por políticas e tomadas de decisões

\footnotetext{
${ }^{26}$ COUTINHO, Diogo R. Direito, desigualdade e desenvolvimento. São Paulo: Saraiva, 2013. p. 56.

${ }^{27}$ COUTINHO, Diogo R. Direito, desigualdade e desenvolvimento. São Paulo: Saraiva, 2013. p. 57.

${ }^{28}$ COUTINHO, Diogo R. Direito, desigualdade e desenvolvimento. São Paulo: Saraiva, 2013. p. 55.
} 
internacionais dos agentes econômicos, e tais circunstâncias devem ser objeto de observação das empresas locais.

A desigualdade é um fator preponderante na exclusão social, e um dos maiores desafios da sociedade pós-moderna é justamente o de "reinserir todos os indivíduos na sociedade e lhes garantir meios para que gozem de uma vida digna". ${ }^{29}$ Se a globalização e a acumulação de riquezas próprias do capitalismo clássico são fonte de desigualdade e de exclusão social, necessário que se traga a este mundo pós-moderno uma nova forma de capitalismo que proporcione dignidade ao indivíduo.

0 mundo globalizado vem sofrendo as consequências oriundas da crise econômica iniciada em 2008, havendo grande preocupação dos governantes em redimensionar as economias para um progresso desenvolvimentista. No Brasil, além das influências negativas da crise mundial, a crise política e institucional decorrente da operação “Lava-Jato" tem sujeitado a população ao maior nível de desemprego de sua história.

Segundo dados da OIT - Organização Mundial do Trabalho-, em relatório de 2016, a perspectiva de desemprego para 2017 era de uma população em torno de 3,4 milhões de pessoas. $^{30}$ Apenas no Brasil, de acordo com dados do Instituto Brasileiro de Geografia e Estatística (IBGE), em Pesquisa Nacional por Amostra de Domicílios Contínua (Pnad) - IBGE-PNAD -, o nível de desemprego em 2017 atingiu a significativa marca de 13,547 milhões de pessoas. ${ }^{31}$

29 DUARTE, Juliana. Teoria jus-humanista multidimensional do trabalho sob a perspectiva do capitalismo humanista. Rio de Janeiro: Lumen Juris, 2015. p. 1.

30 ORGANIZAÇÃO INTERNACIONAL DO TRABALHO. Perspectivas sociales y del empleo en el mundo Tendencias 2017. Disponível em: <http://www.ilo.org/wcmsp5/groups/public/---dgreports/---dcomm/--publ/documents/publication/wcms_540901.pdf>. Acesso em: 21 abr. 2017.

31 INSTITUTO BRASILEIRO DE GEOGRAFIA E ESTATÍ́STICA. Pesquisa Nacional por Amostra de Domicílios Contínua (Pnad). 2017. Disponível em: <http://br.advfn.com/indicadores/pnad>. Acesso em: $21 \mathrm{abr}$. 2017. 


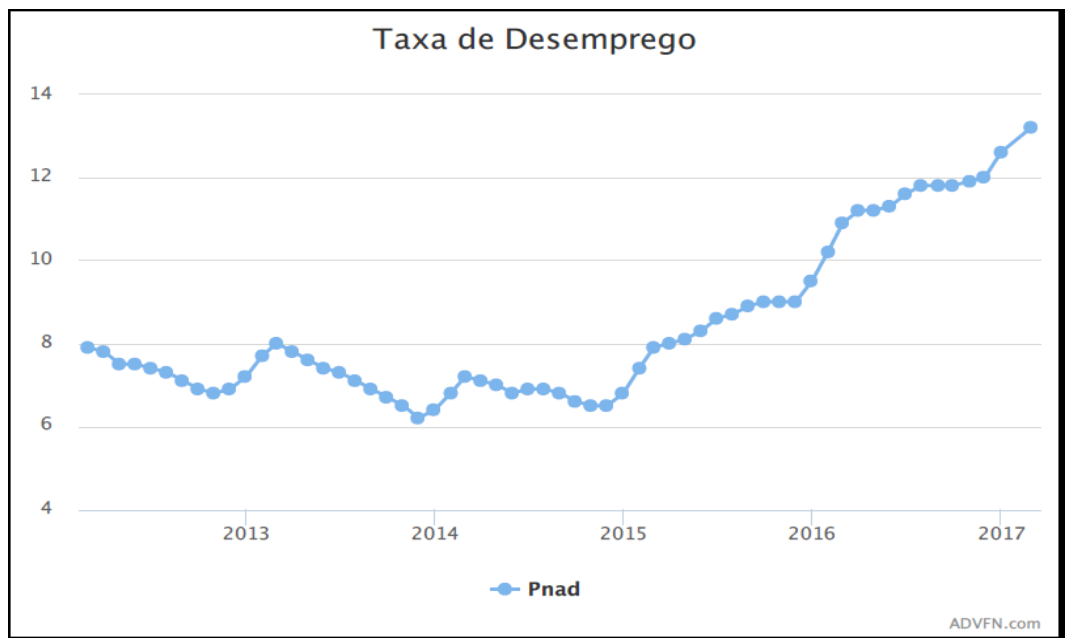

Fonte: INSTITUTO BRASILEIRO DE GEOGRAFIA E ESTATÍSTICA. Pesquisa Nacional por Amostra de Domicílios Contínua (Pnad). 2017. Disponível em: <http://br.advfn.com/indicadores/pnad $>$. Acesso em: 21 abr. 2017.

Esses dados apontam que o Brasil superou as expectativas internacionais de desemprego, o que demonstra a gravidade dos problemas internos oriundos de uma crise institucional e política sem precedentes na história brasileira. O desemprego no Brasil chegou a ser objeto de observação no relatório da OIT-Organização Internacional do trabalho:

Prevê-se que os níveis e taxas de desemprego mundiais se mantenham em níveis elevados no curto prazo, pois a força de trabalho global continua a crescer. Em particular, espera-se que a taxa de desemprego global registre um aumento modesto e passe de 5,7 por cento em 2016 para 5,8 por cento em 2017. Este aumento representa 3,4 milhões mais de pessoas desempregadas em todo o mundo, com o qual o desemprego total seria superior a 201 milhões em 2017. Enquanto projeta-se que a taxa de desemprego global vai permanecer relativamente estável em 2018, a taxa de crescimento da mão de obra (ou seja, aqueles que procuram emprego) excederá a criação de emprego, posto que 2,7 milhões de pessoas a mais estarão desempregadas em todo o mundo.

O aumento dos níveis e taxas de desemprego em 2017 tenderão a subir em razão da deterioração das condições do mercado de trabalho nos países emergentes: os efeitos de várias recessões profundas que tiveram lugar em 2016 continuarão a afetar os mercados de trabalho em 2017. Na verdade, prevê-se que em países emergentes 3,6 milhões mais pessoas estarão desempregadas entre 2016 e 2017. Espera-se que no mesmo período a taxa de desemprego nestes países seja em torno de 5,6 a 5,7 por cento. A situação na América Latina e no Caribe tem gerado preocupação especial porque há uma previsão de que a taxa de desemprego aumentará de 0,3 pontos percentuais em 2017 para 8,4 por cento 
(principalmente em razão do aumento do desemprego no Brasil). ${ }^{32}$ (tradução livre)

A utilização da propriedade e do capital tem servido nos últimos séculos ao proveito quase exclusivo do detentor do domínio, como meio de agregação de lucros, sem que tal circunstância tenha relevo no aspecto relacionado ao indivíduo como ente social pertencente a este processo. Esse "acúmulo de riquezas, sem qualquer preocupação com o próximo, apenas com o bem-estar pessoal, decorrente de um sistema neoliberal, amplia assustadoramente 0 número de pessoas que habitam este Planeta privadas do mínimo vital e socialmente excluídas" ${ }^{33}$.

A perspectiva neoliberal do mundo capitalista precisa ser relativizada para colocar o ser humano como centro e fim dos recursos existentes no planeta e não como meio, um simples objeto a se tornar abjeto nas mãos do poder econômico e político. Para Ricardo Hasson Sayeg, um dos precursores da teoria do Capitalismo Humanista, a pretensão não seria de abandonar o capitalismo, mas controlar seus inconvenientes, através da concreção universal dos direitos humanos nas três dimensões exsurgidas com a Revolução Francesa de 1789 - Liberdade, Igualdade e Fraternidade-, por meio de uma nova forma jurídica de tratamento da economia, "elevando o mercado, de sua conhecida e mítica condição de ambiente selvagem e desumano, a uma economia humanista de mercado para satisfação universal do direito objetivo inato,

\footnotetext{
32 "Se prevé que los niveles y tasas de desempleo mundial se mantengan elevados a corto plazo, pues la mano de obra mundial sigue creciendo. En particular, se espera que la tasa de desempleo mundial registre un modesto incremento y pase del 5,7 por ciento en 2016 al 5,8 por ciento en 2017. Este aumento supone 3,4 millones más de personas desempleadas en todo el mundo, con lo cual el desempleo total superaría los 201 millones en 2017. Si bien se proyecta que la tasa de desempleo mundial se mantendrá relativamente estable en 2018, el ritmo de crecimiento de la mano de obra (es decir, de aquellos que buscan empleo) rebasará la creación de empleo, por lo cual 2,7 millones de personas más estarán en situación de desempleo en todo el mundo.

El incremento de los niveles y tasas de desempleo en 2017 tendrá origen en el deterioro de las condiciones del mercado de trabajo en los países emergentes: los efectos de varias recesiones profundas que tuvieron lugar en 2016 seguirán afectando a los mercados de trabajo en 2017. De hecho, se prevê que en los países emergentes 3,6 millones más de personas estarán en situación de desempleo entre 2016 y 2017. Se espera que en el mismo periodo la tasa de desempleo en estos países pase del 5,6 al 5,7 por ciento. La situación en América Latina y el Caribe genera particular preocupación, pues se proyecta que la tasa de desempleo aumentará 0,3 puntos porcentuales en 2017 hasta alcanzar el 8,4 por ciento (sobre todo, debido al incremento del desempleo en el Brasil)" ORGANIZAÇÃO INTERNACIONAL DO TRABALHO. Perspectivas sociales y del empleo en el mundo - Tendencias 2017. Disponível em: $<$ http://www.ilo.org/wcmsp5/groups/public/---dgreports/---dcomm/--publ/documents/publication/wcms_540901.pdf>. Acesso em: 21 abr. 2017. p. 1.

33 DUARTE, Juliana. Teoria jus-humanista multidimensional do trabalho sob a perspectiva do capitalismo humanista. Rio de Janeiro: Lumen Juris, 2015. p. 7.
} 
correspondente à dignidade da pessoa humana em suas dimensões de democracia e paz" ${ }^{34}$. $\mathrm{Na}$ visão de Ricardo Sayeg, essa mudança filosófica é possível por meio de alterações humanistas em favor do homem.

O fundamento jus filosófico do capitalismo humanista tem em uma de suas bases a Declaração Universal dos Direitos Humanos, que estabelece princípios consagradores da defesa do homem e de sua dignidade em uma cadeia de direitos e deveres que permeiam os caminhos para uma redefinição das estruturas dos Estados, dos organismos internacionais, e uma necessária reestruturação normativa que possibilite o controle da economia globalizada e os fundamentos econômicos em que se apoiam os mercados. O capitalismo como obra humana moldou-se na forma neoliberal utilizada pelos países da economia globalizada, que a elevaram ao status de política econômica para o mundo, servindo apenas e tão somente aos mercados. ${ }^{35}$

A partir do Consenso de Washington, em 1989, o neoliberalismo conduziu o mundo a uma ampla e global economia de mercado, numa "retomada concreta das clássicas teorias liberais econômicas de Adam Smith e David Ricardo" ${ }^{36}$, impulsionando o planeta a uma escalada sem precedentes que proporcionou a implantação da globalização e suas mazelas, que foram objeto de discussão anteriormente neste trabalho. 0 capitalismo neoliberal se alavanca por meio da expressão econômica clássica, segundo a qual a "mão invisível” da economia baliza as alternativas por meio de sua própria dinâmica ${ }^{37}$. Comparato, utilizando a fraseologia de Adam Smith, elucida que, embora ele não tenha justificado de modo ético o egoísmo, a concepção da alegoria da "mão invisível”, a procura dos múltiplos interesses individuais, conduz de modo reflexo à realização do bem comum ${ }^{38}$.

Ao preferir fomentar a atividade do país e não de outros países, ele tem em vista apenas sua própria segurança; e orientando sua atividade de tal maneira que sua produção possa ser de maior valor, visa apenas a seu próprio ganho e, neste, como em muitos outros casos, é levado como que por mão invisível a promover um objetivo que não fazia parte de suas intenções. Aliás, nem sempre é pior para a sociedade que esse objetivo não faça parte das intenções do indivíduo. Ao perseguir seus próprios interesses, o indivíduo muitas vezes promove o interesse

\footnotetext{
${ }^{34}$ SAYEG, Ricaddo Hasson; BALERA, Wagner. O capitalismo humanista. Filosofia humanista de direito econômico. Rio de Janeiro: KBR Editora Digital, 2011.

35 SAYEG, Ricaddo Hasson; BALERA, Wagner. 0 capitalismo humanista. Filosofia humanista de direito econômico. Rio de Janeiro: KBR Editora Digital, 2011.

${ }^{36}$ SAYEG, Ricaddo Hasson; BALERA, Wagner. O capitalismo humanista. Filosofia humanista de direito econômico. Rio de Janeiro: KBR Editora Digital, 2011.

${ }^{37}$ SAYEG, Ricaddo Hasson; BALERA, Wagner. 0 capitalismo humanista. Filosofia humanista de direito econômico. Rio de Janeiro: KBR Editora Digital, 2011. p. 19.

${ }^{38}$ COMPARATO, Fábio Konder. A civilização capitalista: para compreender o mundo em que vivemos. 2 ed. São Paulo: Saraiva, 2014. p. 50.
} 
da sociedade muito mais eficazmente do que quando tenciona realmente promovê-lo. $^{39}$

Não obstante, a globalização, na forma como é conhecida no mundo contemporâneo, conduz o homem a conviver em ambiente selvagem, reduzindo-o a uma menor significância. Ricardo Sayeg enfatiza que:

\begin{abstract}
Esse estado de coisas representa, sem mais nem menos, a transposição para a economia, e sob a complacência do direito, da lei biológica da seleção natural de Darwin - em que prevalecem no estado de natureza e selvageria e a desumanidade, sobrevivendo o mais apto com o descarte do inapto.

Assim, a exclusão econômica, social, política e cultural, como também o esgotamento do planeta, são considerados naturais, tudo em prol da seleção natural e de um crescimento econômico onde os ricos ficam mais ricos e os pobres, mais pobres.

[...]

Aproveitando-se da bancarrota do socialismo, os países ricos passaram a afirmar que não há resposta suficiente ao capitalismo liberal; em consequência, querem devolver a humanidade, no ambiente econômico, ao estado de natureza selvagem" ${ }^{40}$.
\end{abstract}

Conquanto a implementação do capitalismo humanista possa tornar-se apenas uma teoria filosófica, dadas as dificuldades de sua implementação em concreto no ambiente globalizado em que se encontra a economia pós-moderna, em ambiente de sociedade informacional fartamente impactado pelas tecnologias, necessário que sua concreção se inicie por meio da efetiva subsunção de nossa realidade fática ao sistema jurídico constitucional a que estamos submetidos.

O legado normativo e constitucional brasileiro já tem em suas raias os pressupostos fundantes de um direito econômico que possa diminuir as desigualdades sociais, utilizando-se para tanto o arcabouço legalista incorporado de fato no ordenamento jurídico nacional, como será visto à frente.

\title{
3 A FUNÇÃO SOCIAL DA EMPRESA
}

\subsection{Previsão Legal}

\footnotetext{
${ }^{39}$ SMITH, Adam. A riqueza das nações - investigação sobre sua natureza e suas causas. Tradução de Luiz João Baraúna. São Paulo: Nova Cultural, 1996. p. 438.

40 SAYEG, Ricaddo Hasson; BALERA, Wagner. 0 capitalismo humanista. Filosofia humanista de direito econômico. Rio de Janeiro: KBR Editora Digital, 2011. p. 19.
} 
A função social da propriedade passou a fazer parte do direito positivado com a promulgação da Constituição Alemã de Weimar em 1919, reproduzida posteriormente pela Constituição da República Federal da Alemanha de 1949, art. 14, $2^{\mathrm{a}}$ alínea: “A propriedade obriga. Seu uso deve, ao mesmo tempo, servir o interesse da coletividade' (Eigentumverpflichtet. SeinGebrauchsollaugleichdemWhole der Allgemeinheitdienen)." No Código Civil italiano, o art. 838 contempla a possibilidade de expropriação quando “o proprietário abandona a conservação, o cultivo ou o exercício de bens que interessa à produção nacional". ${ }^{41}$

Quando se fomenta a implantação de um capitalismo humanista, pode parecer que o complexo legalista nacional não estaria apto a possibilitar tal dimensão de modo concreto e realista. Contudo, impende observar que a Constituição Brasileira contém dispositivos de natureza constitucional que contemplam princípios consagradores da cidadania, da dignidade da pessoa humana e precursores dos valores sociais do trabalho e da livre iniciativa (CF. art. $1^{\circ}$ incisos II, III e IV).

No preâmbulo da Constituição estão inseridas as diretrizes de um Estado Democrático que é destinado a assegurar o exercício dos direitos sociais e individuais, a liberdade, a segurança, o bem-estar, o desenvolvimento, a igualdade e a justiça como valores supremos de uma sociedade fraterna, pluralista e sem preconceitos, fundada na harmonia social e comprometida, na ordem interna e internacional, com a solução pacífica das controvérsias.

No art. $5^{\circ}$, no Título II que contempla os Direitos e Garantias Fundamentais e os direitos e deveres individuais e coletivos, tem-se a previsão do inciso XXIII, pelo qual a propriedade atenderá a sua função social. Logo à frente, no Título VII, quando há tratamento das questões voltadas à Ordem Econômica e Financeira, o Capítulo I faz menção aos princípios gerais da atividade econômica, conforme preceitua o art. 170, especificamente o inciso III que destaca o da função social da propriedade. ${ }^{42}$

\footnotetext{
${ }^{41}$ COMPARATO, Fábio Konder. Função social de propriedade dos bens de produção. In: COELHO, Fábio Ulhoa (coord.). Tratado de Direito Comercial. São Paulo: Saraiva, 2015. v. 1. p. 130.

${ }^{42}$ BRASIL. Constituição Federal. Diário Oficial da República Federativa do Brasil, Brasília, 5 out. 1988. Disponível em: <http://www.planalto.gov.br/ccivil_03/constituicao/constituicaocompilado.htm>. Acesso em: 16 jun. 2017.

Art. 170. A ordem econômica, fundada na valorização do trabalho humano e na livre iniciativa, tem por fim assegurar a todos existência digna, conforme os ditames da justiça social, observados os seguintes princípios: I - soberania nacional; II - propriedade privada; III - função social da propriedade; IV - livre concorrência; V - defesa do consumidor; Vl - defesa do meio ambiente, inclusive mediante tratamento diferenciado conforme o impacto ambiental dos produtos e serviços e de seus processos de elaboração e prestação; VII - redução das desigualdades regionais e sociais; VIII - busca do pleno emprego; IX -
} 
Sobre a função social da propriedade, cumpre ainda comentar a previsão do parágrafo $2^{\circ}$ do art. 182 da Constituição Federal, quando trata da Política Urbana, pelo qual se define que a propriedade urbana cumpre sua função social quando atende às exigências fundamentais de ordenação da cidade expressas no plano diretor. Por fim, No Capítulo III, quando a Constituição Federal trata da política agrícola e fundiária e da reforma agrária, nos artigos 184 e, especificamente, no 186, em que o princípio da função social da propriedade tem sua proeminência prevista. $^{43}$

No Código Civil, conforme previsão do $\S 1^{\circ}$ do art. 1.228, o direito de propriedade deve ser exercido em consonância com as suas finalidades econômicas e sociais e de modo que sejam preservados, de conformidade com o estabelecido em lei especial, a flora, a fauna, as belezas naturais, o equilíbrio ecológico e o patrimônio histórico e artístico, bem como evitada a poluição do ar e das águas, constando ainda no art. 421 que a liberdade de contratar será exercida em razão e nos limites da função social do contrato. O princípio da função social da propriedade recebe tratamento nas disposições transitórias, no parágrafo único do art. 2.035, em que está previsto que nenhuma convenção prevalecerá se contrariar preceitos de ordem pública, tais como os estabelecidos por esse Código para assegurar a função social da propriedade e dos contratos.

No Estatuto da Cidade, lei 10.257 de 2001, a função social da propriedade também recebe tratamento no art. 39, em que praticamente repete a previsão constitucional do art. 182 da Constituição. Na Lei 6.404 de 1976, que dispõe sobre as Sociedades por Ações, tem previsão no parágrafo único do artigo 116, quando faz menção aos deveres do acionista controlador, o qual deve usar o seu poder com o fim de fazer a companhia realizar o seu objeto e cumprir sua função social, e ainda no artigo 154, que impõe ao administrador o dever de exercer as atribuições que a lei e o estatuto the conferem para lograr os fins e no interesse da companhia, satisfeitas as exigências do bem público e da função social da empresa.

tratamento favorecido para as empresas de pequeno porte constituídas sob as leis brasileiras e que tenham sua sede e administração no País. Parágrafo único. É assegurado a todos o livre exercício de qualquer atividade econômica, independentemente de autorização de órgãos públicos, salvo nos casos previstos em lei.

${ }^{43}$ BRASIL. Constituição Federal. Diário Oficial da República Federativa do Brasil, Brasília, 5 out. 1988. Disponível em: <http://www.planalto.gov.br/ccivil_03/constituicao/constituicaocompilado.htm>. Acesso em: 16 jun. 2017.

Art. 186. A função social é cumprida quando a propriedade rural atende, simultaneamente, segundo critérios e graus de exigência estabelecidos em lei, aos seguintes requisitos: I - aproveitamento racional e adequado; II - utilização adequada dos recursos naturais disponíveis e preservação do meio ambiente; III observância das disposições que regulam as relações de trabalho; IV - exploração que favoreça o bemestar dos proprietários e dos trabalhadores. 


\subsection{Objetivos da Função Social da Empresa}

No ordenamento jurídico constitucional, a função social da empresa e da propriedade recebe tratamento específico, valendo dizer que a partir do preceito constitucionalmente estratificado, a propriedade privada, também garantida na constituição, não é mais considerada de modo exclusivo ao puro direito individual, na medida em que seu conceito foi relativizado com o fim de assegurar a todos existência digna, por meio do conceito de propriedade e da aplicação dos princípios da ordem econômica, conforme os ditames da justiça social. ${ }^{44}$

Para o uso da propriedade, considerando-se os ditames constitucionais de finalidade social, especialmente no art. $3^{\circ}$, como instrumento para a realização da finalidade, com a criação de uma sociedade justa e solidária, com redução das desigualdades sociais e respeito à dignidade da pessoa humana, tendo como destinatário toda a sociedade, preconiza-se o entendimento de que deve haver compatibilização entre os interesses privados do proprietário, com o respeito ao meio ambiente, à destinação produtiva do imóvel rural, com evidente proteção dos trabalhadores rurais. ${ }^{45}$

$\mathrm{Na}$ avaliação conceitual da função social da propriedade de bens de produção, Fábio Konder Comparato alerta para o fato de que, ao se falar em função social da propriedade, não se está a indicar as restrições ao uso e gozo dos bens próprios, sendo estas últimas os limites negativos ao direito de propriedade, porém a interpretação de função tem o significado de um poder de dar ao objeto da propriedade um destino determinado de modo a associá-lo a um objetivo. No momento em que a esse objetivo é acrescentado o adjetivo social, cria-se uma correspondência da função social da propriedade ao interesse coletivo, correspondendo aquela a um poder-dever do proprietário em the dar essa destinação, compatível com o interesse da coletividade $^{46}$, sujeitando-se à sanção pela ordem pública. ${ }^{47}$

\footnotetext{
${ }^{44}$ FACHINI NETO, EUGÊNIO. A função social da propriedade e o direito constitucional brasileiro. Breves notas. In: J. J. Gomes Canotilho et al. Comentários à Constituição do Brasil. São Paulo: Saraiva/Almedina, 2013, comentário ao art. 170.

${ }_{45}$ FACHINI NETO, EUGÊNIO. A função social da propriedade e o direito constitucional brasileiro. Breves notas. In: J. J. Gomes Canotilho et al. Comentários à Constituição do Brasil. São Paulo: Saraiva/Almedina, 2013, comentário ao art. 170.

${ }_{46}$ COMPARATO, Fábio Konder. Função social de propriedade dos bens de produção. In: COELHO, Fábio Ulhôa (Coord.). Tratado de Direito Comercial. São Paulo: Saraiva, 2015. v. 1. p. 132.

${ }^{47}$ COMPARATO, Fábio Konder. Função social de propriedade dos bens de produção. In: COELHO, Fábio Ulhôa (Coord.). Tratado de Direito Comercial. São Paulo: Saraiva, 2015. v. 1. p. 130.
} 
Os argumentos lançados por Fábio Konder Comparato, na conformidade exarada no trecho anterior, no entanto, são observados de forma mais contundente, com conotação diversa da função social da empresa que ora observamos em sua posição mais recente, quando analisamos seu pensamento jurídico em texto de 1996, em que suas conclusões sobre a tese da função social da empresa estavam mais direcionadas às questões de natureza que se aproximam de uma posição eminentemente retórica do que propriamente ao efetivo exercício, pelas empresas, de uma atividade que atingisse os fins elencados na norma constitucional.

Para Fábio Konder Comparato, em sua análise sobre a função social da empresa, especificamente sobre a lei das sociedade por ações, Lei 6.404 de 1976, esta reconhece que no exercício da atividade empresarial há interesses internos e externos que devem ser respeitados, não apenas os direitos das pessoas que contribuem diretamente para a operação da empresa, como também os investidores - os capitalistas - e trabalhadores, mas também os interesses da comunidade em que ela atua, sendo estes consistentes aos deveres negativos do empresário, representando a mera aplicação do princípio neminemlaedere. Porém, em relação aos deveres positivos do empresário, Fábio Comparato chegou a dizer de modo expresso que o conceito de função social das empresas tem alcance limitado, senão nulo, como conclusão do questionamento que faz acerca das obrigações do empresário:

[...] Fora do elenco dos direitos trabalhistas do art. $7^{\circ}$ da Constituição, por exemplo, teriam as empresas o dever de desenvolver um plano de assistência social ou de previdência complementar para seus empregados? 0 art. 116, parágrafo único, da Lei 6.404 obrigaria, porventura, o acionista controlador a fazer com que a companhia participasse de campanhas de recolhimento e amparo de menores abandonados, lançados pelo governo do Município onde tem a sua sede? Mais especificamente, em caso de conflito entre o interesse próprio da empresa, como unidade econômica, e o interesse geral da coletividade, deve o empresário sacrificar o interesse empresarial em prol do bem comum, deixando, por exemplo, de aumentar os preços dos produtos ou serviços de primeira necessidade, sem estar a isso legalmente obrigado ${ }^{48}$

No entender de Comparato, ao contrário do que se possa imaginar sobre a efetiva concretização da função social das empresas, sua finalidade maior seria a de obter lucros, o “objetivo da empresa, ou seja, o exercício de uma atividade econômica de produção ou

${ }^{48}$ COMPARATO, Fábio Konder. Estado, empresa e função social. Revista dos Tribunais, São Paulo, n. 732, out. 1996. p. 44. 
distribuição de bens, ou de prestação de serviços, está sempre subordinado ao objetivo final de apuração e distribuição de lucros."49

É imperioso reconhecer, por conseguinte, a incongruência em se falar numa função social das empresas. No regime capitalista, o que se espera e exige delas é, apenas, a eficiência lucrativa, admitindo-se que, em busca do lucro, o sistema empresarial como um todo exerça a tarefa necessária de produzir ou distribuir bens e de prestar serviços no espaço de um mercado concorrencial. Mas é uma perigosa ilusão imaginar-se que, no desempenho dessa atividade econômica, o sistema empresarial, livre de todo controle dos Poderes Públicos, suprirá naturalmente as carências sociais e evitará os abusos; em suma, promoverá a justiça social. ${ }^{50}$

Newton De Luca, perscrutando as últimas obras de Fábio Konder Comparato, expende que seu posicionamento parece indicar senão uma mudança doutrinária, uma maneira menos inexorável na observação da função social das empresas, no sentido de que, pela sua avaliação,

[...] o século XXI se acha numa verdadeira encruzilhada, diante da qual a humanidade deverá escolher qual das vertentes históricas irá seguir: a que se afunda no poderio bélico, na dominação tecnológica e na progressiva concentração do poder econômico; ou, ao revés, será aquela que ainda tenta se escorar, um tanto quanto heroicamente, na dignidade transcendente da pessoa humana? ${ }^{51}$

Muito embora tenha havido, aparentemente, mudanças no posicionamento de Fábio Konder Comparato, o entendimento sobre a função social das empresas não pode seguir o simples entendimento de que o empresário e as empresas exerçam suas atividades com vistas unicamente ao lucro, como exemplo mais grotesco do capitalismo clássico e selvagem. A função social das empresas, como exposto no presente trabalho, deve seguir as orientações humanistas, como critério de justiça social com objetivo de permitir à sociedade uma vida digna, corolário dos princípios constitucionais republicanos.

\footnotetext{
${ }^{49}$ COMPARATO, Fábio Konder. Estado, empresa e função social. Revista dos Tribunais, São Paulo, n. 732, out. 1996. p. 45

${ }^{50}$ COMPARATO, Fábio Konder. Estado, empresa e função social. Revista dos Tribunais, São Paulo, n. 732, out. 1996. p. 45.

51 LUCCA, Newton de. A função social da empresa. In: COELHO, Fábio Ulhoa (Coord.). Tratado de Direito Comercial. São Paulo: Saraiva, 2015. v. 1. p. 157.
} 
Concordamos com Eros Grau quando esclarece que, pela aplicação do princípio da função social da propriedade, o detentor do domínio exerce seu poder não apenas em benefício de outrem e não apenas a obrigação de não causar prejuízo a outrem ${ }^{52}$ :

O que mais releva enfatizar, entretanto, é o fato de que o princípio da função social da propriedade impõe ao proprietário - ou a quem detém o poder de controle, na empresa - o dever de exercê-lo em benefício de outrem e não, apenas, de não o exercer em prejuízo de outrem. Isso significa que a função social da propriedade atua como fonte da imposição de comportamentos positivos - prestação de fazer, portanto, e não, meramente, de não fazer - ao detentor do poder que deflui da propriedade. Vinculação inteiramente distinta, pois, daquela que lhe é imposta mercê de concreção do poder de polícia. ${ }^{53}$

Para Eros Grau,

[...] o que atualmente divisamos, nas propriedades impregnadas pelo princípio, são verdadeiras propriedades-função social e não apenas, simplesmente, propriedades. 0 princípio da função social da propriedade, desta sorte, passa a integrar o conceito jurídico-positivo de propriedade (destas propriedades), de modo a determinar profundas alterações estruturais na sua inferioridade. ${ }^{54}$

No entendimento de Ana Frazão de Azevedo Lopes, com a qual também concordamos, o Brasil é detentor de uma legislação que "reconhece como direitos e princípios fundamentais a propriedade privada e a livre iniciativa, mas os condiciona à realização da dignidade da pessoa humana" ${ }^{25}$ e aos demais princípios esculpidos nos artigos $1^{\circ}$ e $3^{\circ}$ da Constituição Federal.

Sobreleva observar que a função social da empresa deve ser vista diferentemente da ilação emanada de Fábio Konder Comparato, pois não há mais espaço no mundo contemporâneo para o individualismo exacerbado do capitalismo neoliberal. A busca unicamente do lucro em detrimento de qualquer outra preocupação que não seja àquela restrita ao ambiente corporativo e dos investidores e acionistas cuida-se de uma vertente do liberalismo clássico encontrado em Adam Smith e David Ricardo, defensores ferrenhos do capitalismo liberal.

De encontro à forma relativizada da função social da propriedade, Ana Frazão de Azevedo Lopes apud Perlingieri, em consonância do direcionamento contemporâneo sobre o tema, elucida que além das prerrogativas inerentes à propriedade de usar, gozar e dispor, a

\footnotetext{
${ }^{52}$ GRAU, Eros. A ordem econômica na Constituição de 1988. 14. ed. São Paulo: Malheiros, 2010. p. 250.

${ }^{53}$ GRAU, Eros. A ordem econômica na Constituição de 1988. 14. ed. São Paulo: Malheiros, 2010. p. 250.

${ }^{54}$ GRAU, Eros. A ordem econômica na Constituição de 1988. 14. ed. São Paulo: Malheiros, 2010. p. 241.

55 LOPES, Ana Frazão de Azevedo. Empresa e propriedade - função social e abuso de poder econômico. São Paulo: Quartier Latin, 2006. p. 23.
} 
aplicação do princípio da função social acarreta ao proprietário não apenas as obrigações negativas, neminemlaedere, mas também obrigações positivas em favor da coletividade, conduzindo e orientando sua conduta para a realização do interesse comum. ${ }^{56}$

A função social da empresa deve estar afeta aos desígnios constantes na legislação constitucional brasileira que prima, não por uma tentativa de socializar o capital, mas conceder através do capitalismo humanista uma condição digna à sociedade e ao ambiente envolto à empresa. Afinal, a empresa como instrumento de criação de valor não atua isoladamente e não está desvinculada de suas responsabilidades sociais com seus empregados, fornecedores, consumidores, a comunidade onde está inserida, o meio ambiente em que se instalou, enfim, em todas as estruturas que se interpenetram na busca dos fins sociais a que se propõe a empresa.

A dignidade da pessoa humana, a cidadania, os valores sociais do trabalho e da livre iniciativa e demais princípios constitucionais estão diretamente impingidos não apenas aos entes estatais, União, Estados e Municípios, mas a toda a sociedade, pessoas naturais e empresas, que devem contribuir positivamente com a construção e desenvolvimento da nação. Nesse aspecto, destaca-se o desenvolvimento da cidadania que, de acordo com Marshall, passou pela evolução de três direitos, a saber: o direito civil, o direito político e o direito social, cujo desenvolvimento tem como estimulo a luta para adquirir esses direitos e para mantê-los, uma vez adquiridos. A cidadania, para se concretizar nesse cenário de desenvolvimento, exige uma conexão fundada em sentimento de participação direta da comunidade com base numa lealdade e em uma civilização que é considerada patrimônio comum, compreendendo lealdade de homens livres, imerso de direitos, mas também protegidos por uma lei comum. ${ }^{57}$

$\mathrm{Na}$ visão capitalista neoliberal, o homem é mero instrumento, um meio para se conseguir o tão almejado lucro nas atividades empresariais. Contudo, preferimos nos ater à visão kantiana de liberdade e autonomia, em que a liberdade não possui um sentido exclusivamente negativo, tal como a faculdade de fazer o que as leis não proíbem, mas que tal liberdade deve ser vista de modo positivo, na medida em que os homens devem ser considerados como fins e não como meios, associando-se com a noção de dignidade da pessoa humana. ${ }^{58}$

Kant, ao observar a relação do homem e da dignidade, enfatiza que:

\footnotetext{
${ }^{56}$ LOPES, Ana Frazão de Azevedo. Empresa e propriedade - função social e abuso de poder econômico. São Paulo: Quartier Latin, 2006. p. 121.

${ }^{57}$ MARSHALL, T.H. Cidadania, Classe Social e Status. Rio de Janeiro: Zahar, 1967. p. 84.

${ }^{58}$ MARSHALL, T.H. Cidadania, Classe Social e Status. Rio de Janeiro: Zahar, 1967. p. 42.
} 
No reino dos fins tudo tem ou um preço ou uma dignidade. Quando uma coisa tem um preço, pode-se pôr em vez dela qualquer outra como equivalente; mas quando uma coisa está acima de todo o preço, e, portanto, não permite equivalente, então tem ela dignidade.

0 que se relaciona com as inclinações e necessidades gerais do homem tem um preço venal; aquilo que, mesmo sem pressupor uma necessidade, é conforme a um certo gosto, isto é a uma satisfação no jogo livre e sem finalidade das nossas faculdades anímicas, tem um preço de afeição ou de sentimento (Affektionspreis); aquilo porém que constitui a condição só graças à qual qualquer coisa pode ser um fim em si mesma, não tem somente um valor relativo, isto é um preço, mas um valor íntimo, isto é dignidade.

Robert Alexy enaltece que a formulação da ideia de dignidade humana se coaduna com o conceito de direitos humanos, o que significa dizer que a dignidade humana pressupõe direitos humanos. ${ }^{59}$ Com fundamento nesse conceito Alexy formula a ideia de que o princípio da dignidade humana é o único que pode estar ao lado dos direitos fundamentais sociais constitucionais em todos os casos. Essa ilação foi estruturada a partir do conceito de pessoa de Alexy, denominado duplo-triádico, segundo o qual, para ser considerado pessoa, deve-se cumprir três condições, em duplo turno, seguidamente - duas tríades: a primeira é a inteligência, a segunda, o sentimento, e a terceira, a consciência ou autoconsciência. Esta última, a mais importante, é definida pela reflexividade, distinguindo-se a reflexividade cognitiva, a reflexividade volitiva e a reflexividade normativa.

Alguém que preencha todas as condições mencionadas é uma pessoa, atribuindo-lhe neste caso o lado descritivo da dignidade humana. Para Alexy, o percurso para o lado normativo se inicia com a ligação entre o conceito de pessoa e o conceito de dignidade humana, cuja relação se observa nas seguintes expressões: “1) Todas as pessoas possuem dignidade; 2) A dignidade humana confere a todos os seres humanos o direito a serem levados a sério como pessoas; e 3) Todos os seres humanos têm o direito a serem levados a sério como pessoas."60

Sarlet sobreleva que a concepção sobre a dignidade da pessoa humana de Immanuel Kant é particularmente significativa, pois além de considerar a autonomia como fundamento da

\footnotetext{
${ }^{59}$ ALEXY, Robert. Direitos fundamentais sociais e proporcionalidade. Tradução de Rogério Luiz Nery da Silva. In: ALEXY, Robert; BAEZ, Narciso Leandro Xavier; SILVA, Rogério Luiz Nery da (Org.) Dignidade humana, direitos sociais e não-positivismo inclusivo. Florianópolis: Qualis, 2015. p. 169.

${ }^{60}$ ALEXY, Robert. Direitos fundamentais sociais e proporcionalidade. Tradução de Rogério Luiz Nery da Silva. In: ALEXY, Robert; BAEZ, Narciso Leandro Xavier; SILVA, Rogério Luiz Nery da (Org.) Dignidade humana, direitos sociais e não-positivismo inclusivo. Florianópolis: Qualis, 2015. p. 171.
} 
dignidade do homem sustenta "que o ser humano (o indivíduo) não pode ser tratado - nem por ele próprio - como objeto." 61

$\mathrm{Na}$ esteira dos argumentos de Kant, de Alexy e de Sarlet, cumpre exaltar que a dignidade humana como corolário dos direitos humanos é o fundamento para a aplicação do capitalismo humanista em contraponto ao capitalismo neoliberal.

O neoliberalismo conduz as empresas justamente a tratar o homem como mero objeto, descartável e visto apenas como um meio de atingir os seus fins, o lucro. Na perspectiva neoliberal, o Estado deve ter atuação mínima e a economia deve ter a liberdade de se autorregular, na máxima de Adam Smith, permitindo-se que a “mão invisível” cumpra seu papel em sua própria dinâmica, sempre selvagem. ${ }^{62} \mathrm{~A}$ visão neoliberal sobre a economia e o uso da propriedade se contrapõe à ideia de sua finalidade social, e seus adeptos são diametralmente opostos a qualquer forma de dirigismo, seja como forma de intervenção na economia, seja como forma de intervenção na liberdade de utilização da propriedade e sua destinação. ${ }^{63}$

No entender de Ricardo Hasson Sayeg, esta perspectiva capitalista neoliberal é abominável, pois não se aventa a hipótese do homem juntamente com a economia ser destruído e reinventado à sorte dos mercados. ${ }^{64}$ Nesse aspecto, cumpre salientar, no dizer de Ana Frazão de Azevedo Lopes, "que a atividade empresarial apenas é considerada legítima quando decorrente do exercício da autonomia, ou seja, enquanto o projeto do empresário se compatibiliza com o igual direito de todos os membros da sociedade de também realizarem os seus respectivos projetos de vida". ${ }^{65}$

Além disso, a função social da empresa tem como finalidade fundamental condicionar a atividade empresarial à realização da justiça social ${ }^{66}$, como resposta a uma das indagações do presente trabalho, para a possibilidade de se impelir o titular do domínio dos fatores de produção a adotar posturas positivas no uso da propriedade, com vistas à efetivação da teoria da função social da empresa, de modo a que esta tenha em seus objetivos sociais e empresariais,

\footnotetext{
${ }^{61}$ SARLET, Ingo Wolfgang. Dignidade da pessoa humana e direitos fundamentais na Constituição Federal de 1988. 4. ed. Porto Alegre: Livraria do Advogado, 2006. p. 32.

62 SAYEG, Ricardo Hasson; BALERA, Wagner. 0 capitalismo humanista. Filosofia humanista de direito econômico. Rio de Janeiro: KBR Editora Digital, 2011.

${ }^{63}$ LOPES, Ana Frazão de Azevedo. Empresa e propriedade - função social e abuso de poder econômico. São Paulo: Quartier Latin, 2006. p. 205.

${ }^{64}$ SAYEG, Ricardo Hasson; BALERA, Wagner. 0 capitalismo humanista. Filosofia humanista de direito econômico. Rio de Janeiro: KBR Editora Digital, 2011.

${ }^{65}$ LOPES, Ana Frazão de Azevedo. Empresa e propriedade - função social e abuso de poder econômico. São Paulo: Quartier Latin, 2006. p. 278.

${ }^{66}$ LOPES, Ana Frazão de Azevedo. Empresa e propriedade - função social e abuso de poder econômico. São Paulo: Quartier Latin, 2006. p. 280.
} 
em harmonia com os objetivos sociais traçados pelo regime democrático e republicano brasileiro, o de fomentar o progresso para uma sociedade menos desigual, condicionando o acesso à propriedade, ao seu uso, gozo e fruição, à abertura e ampliação de oportunidades a todos os brasileiros ${ }^{67}$.

Perscrutando as dimensões do Estado Social, é possível concluir que a função social da empresa pode ser melhor harmonizada com a implantação conjunta da teoria do capitalismo humanista, como forma de proteção dos direitos fundamentais da pessoa humana e de mostrar que a empresa deve se ativar com o compromisso e as responsabilidades sociais necessárias para reinserir a solidariedade social na atividade empresarial com a necessária "distribuição da riqueza e dos benefícios da atividade econômica"68, como instrumento de criação de valor e de múltiplos interesses, com o fim de proporcionar aos cidadãos uma vida com respeito à dignidade da pessoa humana.

\section{CONCLUSÃO}

O grande desafio da sociedade organizada, dentre outros objetivos, é o de possibilitar a justiça social e o respeito à dignidade da pessoa humana, diminuição das desigualdades sociais e proporcionar igualdade de oportunidades aos seus indivíduos. Inegável o exercício pleno do direito de propriedade, bem como o pleno direito à livre iniciativa como formas de fomentar o desenvolvimento. Contudo, cabe ao Estado condicionar o uso e o abuso do direito de propriedade, dando-lhe o fim social tal qual previsto em nosso ordenamento jurídico.

Desde os primórdios do Direito Romano, o instituto da propriedade de natureza individual vem sofrendo evolução, com íntima relação com a forma de desenvolvimento do Estado e sua relação com o indivíduo. O Estado liberal passou a dar espaço ao Estado Social que surgiu da necessidade de se conceder maior amplitude à diminuição das desigualdades sociais, aos direitos individuais e direitos sociais, cabendo ao Estado desempenhar papel importante nesta tarefa por meio da intervenção nos meios econômicos regulando de forma mais justa de modo a trazer equilíbrio nesse processo de desenvolvimento das relações humanas.

\footnotetext{
${ }^{67}$ BANDEIRA DE MELLO, Celso Antônio. Novos Aspectos da Função Social da Propriedade no Direito Público. Revista de Direito Publico - RDP, v. 20, n. 84, out./dez. 1987. p. 44.

${ }^{68}$ LOPES, Ana Frazão de Azevedo. Empresa e propriedade - função social e abuso de poder econômico. São Paulo: Quartier Latin, 2006. p. 281.
} 
A proeminência da força acumulativa do capital em detrimento da força de trabalho, que quase nada acumula, desafia os meios institucionais em perquirir uma justa distribuição de renda em um movimento de avançar no distanciamento do Estado Neoliberal para a proteção do Estado Social.

O desafio do Estado por meio da aplicação do princípio da função social da propriedade e da empresa é o de possibilitar uma melhor distribuição de renda para uma menor desigualdade social. Impor obrigações positivas às empresas no sentido de terem em seus objetivos os benefícios sociais e não apenas o de não prejudicar os consumidores, o meio ambiente, os trabalhadores. As obrigações negativas decorrem de lei, e sua observância é obrigatória.

O neoliberalismo conduziu à globalização que, por sua vez, impôs ao mundo uma nova forma de vida e com mudanças necessárias de paradigmas. A globalização trouxe grandes transformações ao mundo, boas e ruins, mas sua implementação decorreu do apoio dos países neoliberais, e juntamente com as grandes corporações criaram-se mecanismos econômicos que levaram desenvolvimento, mas também concentração de riquezas. A globalização, ao invés de ser uma porta aberta ao desenvolvimento, acaba por ser apontada como uma das causas da desigualdade.

A desigualdade é um fator preponderante na exclusão social. E um dos maiores desafios da sociedade pós-moderna é o de reinserir todos os indivíduos na sociedade e thes garantir meios para que gozem de uma vida digna. O mundo globalizado vem sofrendo as consequências oriundas da crise econômica iniciada em 2008, havendo grande preocupação dos governantes em redimensionar as economias para um progresso desenvolvimentista. No Brasil, além das influências negativas da crise mundial, a crise política interna tem potencializado a crise econômica com grande nível de desemprego e fechamento de empresas.

A perspectiva neoliberal do mundo capitalista precisa ser revista para colocar o ser humano como centro e fim da destinação dos recursos existentes no planeta e não apenas o meio, um simples objeto a serviço do poder econômico. A teoria do Capitalismo Humanista, defendida neste texto, não tem a pretensão de abandonar o capitalismo, mas controlar seus inconvenientes, através da concreção universal dos direitos humanos nas três dimensões exsurgidas com a Revolução Francesa de 1789 - Liberdade, Igualdade e Fraternidade.

O Brasil é detentor de uma legislação que reconhece como direitos e princípios fundamentais a propriedade privada e a livre iniciativa, mas os condiciona à realização da dignidade da pessoa humana e aos demais princípios esculpidos nos artigos $1^{\circ}$ e $3^{\circ}$ da Constituição federal. 
A função social da empresa pode ser observada tanto do ponto de vista do capitalismo humanista como da nova empresarialidade quando se acrescenta valores de eticidade e morais ao exercício da atividade mercantil, pois não há mais espaço no mundo contemporâneo para o individualismo exacerbado do capitalismo neoliberal e a obtenção de riquezas a qualquer preço. A busca unicamente do lucro em detrimento de qualquer outra preocupação que não seja aquela restrita ao ambiente corporativo e dos investidores acionistas, vertente do liberalismo clássico encontrado em Adam Smith e David Ricardo, defensores do capitalismo liberal, deve ceder espaço para outras ideologias que melhor se afeiçoem aos valores sociais buscados em harmonia com as premissas protetivas constitucionais da pessoa humana.

De encontro à forma relativizada da função social da propriedade, em consonância do direcionamento contemporâneo sobre o tema, além das prerrogativas inerentes à propriedade de usar, gozar e dispor, a aplicação do princípio da função social acarreta ao proprietário não apenas as obrigações negativas, neminem laedere, mas também obrigações positivas em favor da coletividade, conduzindo e orientando sua conduta para a realização do interesse comum.

A dignidade da pessoa humana, a cidadania, os valores sociais do trabalho e da livre iniciativa e demais princípios constitucionais estão diretamente impingindo não apenas aos entes estatais, União, Estados e Municípios, mas a toda a sociedade, pessoas naturais e empresas, que devem contribuir positivamente com a construção e desenvolvimento sustentável da nação.

Para a implementação do capitalismo humanista, dando concreção à teoria filosófica que o origina, ou para revestir a atividade empresarial com preceitos de eticidade e valores morais, é necessário que se efetive a subsunção de nossa realidade fática ao sistema jurídico constitucional a que estamos submetidos. O legado normativo e constitucional do ordenamento jurídico nacional já tem em suas raias os princípios e pressupostos fundantes de um direito econômico que possa diminuir as desigualdades sociais, basta interpretação e vontade de aplicação sistêmica.

\section{REFERÊNCIAS}

ALEXY, Robert. Direitos fundamentais sociais e proporcionalidade. Tradução de Rogério Luiz Nery da Silva. In: ALEXY, Robert; BAEZ, Narciso Leandro Xavier; SILVA, Rogério Luiz Nery da (Org.) Dignidade humana, direitos sociais e não-positivismo inclusivo. Florianópolis: Qualis, 2015.

ARDUIN, Ana Lúcia Alves da Costa. A teoria Jurídica da empresa. In: COELHO, Fábio Ulhoa (Coord.). Tratado de Direito Comercial. São Paulo: Saraiva, 2015. v. 1. 
BANDEIRA DE MELLO, Celso Antônio. Novos Aspectos da Função Social da Propriedade no Direito Público. Revista de Direito Público - RDP, v. 20, n. 84, out./dez. 1987.

BRASIL. Constituição Federal. Diário Oficial da República Federativa do Brasil, Brasília, 5 out. 1988. Disponível em:

<http://www.planalto.gov.br/ccivil_03/constituicao/constituicaocompilado.htm>. Acesso em: 16 jun. 2017.

COMPARATO, Fábio Konder. A civilização capitalista: para compreender o mundo em que vivemos. 2 ed. São Paulo: Saraiva, 2014.

COMPARATO, Fábio Konder. Função social de propriedade dos bens de produção. In: COELHO, Fábio Ulhôa (Coord.). Tratado de Direito Comercial. São Paulo: Saraiva, 2015. v. 1.

COMPARATO, Fábio Konder. Estado, empresa e função social. Revista dos Tribunais. São Paulo, n. 732, out. 1996.

COUTINHO, Diogo R. Direito, desigualdade e desenvolvimento. São Paulo: Saraiva, 2013.

DALCERO, Pedro Luiz. Globalização financeira e volatilidade de capitais: a busca de uma alternativa racionalista. Rev. bras. polít. int., Brasília, v. 40, n. 2, p. 131-143, dez. 1997. Disponível em: <http: //www.scielo.br/scielo.php?script=sci_arttext\&pid=S003473291997000200006\&lng=en\&nrm=iso>. Acesso em: 3 set. 2017.

DINIZ, Maria Helena. Código Civil Anotado. 6. ed. São Paulo: Saraiva, 2000.

DUARTE, Juliana. Teoria jus-humanista multidimensional do trabalho sob a perspectiva do capitalismo humanista. Rio de Janeiro: Lumen Juris, 2015.

FACHINI NETO, Eugênio. Comentários ao art. 170. In: CANOTILHO, J. J. Gomes; SARLET, Ingo Wolfgang; STRECK, Lenio Luiz; MENDES, Gilmar Ferreira (Coord.). Comentários à Constituição do Brasil. São Paulo: Saraiva, 2013.

GRAU, Eros. A ordem econômica na Constituição de 1988. 14. ed. São Paulo: Malheiros, 2010.

INSTITUTO BRASILEIRO DE GEOGRAFIA E ESTATÍ́sTICA. Pesquisa Nacional por Amostra de Domicílios Contínua (Pnad). 2017. Disponível em: <http://br.advfn.com/indicadores/pnad>. Acesso em: 21 abr. 2017.

LOPES, Ana Frazão de Azevedo. Empresa e propriedade - função social e abuso de poder econômico. São Paulo: Quartier Latin, 2006.

LUCCA, Newton de. A função social da empresa. In: COELHO, Fábio Ulhoa (Coord.). Tratado de Direito Comercial. São Paulo: Saraiva, 2015. v. 1.

MARSHALL, T.H. Cidadania, Classe Social e Status. Rio de Janeiro: Zahar, 1967. 
MAZZUCATO, Mariana. O estado empreendedor: desmascarando o mito do setor público vs. setor privado. Tradução de Elvira Serapicos. São Paulo: Portfólio-Penguin, 2014.

PADILHA, Norma Sueli; VECHIA, Rosangela. Direito de propriedade e função social da propriedade: os desafios propostos pelo estatuto da cidade. [200-?] Disponível em: <http://www.publicadireito.com.br/conpedi/manaus/arquivos/anais/campos/rosangela_vecchi a.pdf>. Acesso em: 14 out. 2016.

ORGANIZAÇÃO INTERNACIONAL DO TRABALHO. Perspectivas sociales y del empleo en el mundo - Tendencias 2017. Disponível em: <http://www.ilo.org/wcmsp5/groups/public/---dgreports/--dcomm/---publ/documents/publication/wcms_540901.pdf>. Acesso em: 21 abr. 2017.

PEREIRA, Caio Mário da Silva. Instituições de Direito Civil. Rio de Janeiro: Forense, 1990.

ROUSSEAU, Jean-Jacques. Do contrato social ou princípios do direito político. Tradução de Lourdes Santos Machado. São Paulo: Nova Cultural, 1999.

ROCHA, Manoel Ilson Cordeiro. A crise do Estado Social na Europa Ocidental e na América Latina contemporânea e a precarização dos direitos fundamentais sociais: um estudo a partir das referências brasileiras e portuguesas. Revista da Fundação Educacional de Ituverava, Nucleus, Ituverava, v. 13, n. 1, p. 319-325, 2016. Disponível em:

<http://www. nucleus.feituverava.com.br/index.php/nucleus/article/view/1468/2019>. Acesso em: 17 out. 2016.

SANTOS, Milton. Por uma outra globalização. Rio de Janeiro: BestBolso, 2011.

SAYEG, Ricardo Hasson; BALERA, Wagner. O capitalismo humanista. Filosofia humanista de direito econômico. Rio de Janeiro: KBR Editora Digital, 2011.

SARLET, Ingo Wolfgang. Dignidade da pessoa humana e direitos fundamentais na Constituição Federal de 1988. 4. ed. Porto Alegre: Livraria do Advogado, 2006.

SIMÃO FILHO, Adalberto. Direito Societário Contemporâneo. In: BIANCHINI, Aline; GOMES, Luiz Flávio (Coord.). Direito Empresarial III. São Paulo: Saraiva, 2012. v. 28.

SMITH, Adam. A riqueza das nações - investigação sobre sua natureza e suas causas. Tradução de Luiz João Baraúna. São Paulo: Nova Cultural, 1996.

\section{COMO FAZER A REFERÊNCIA DO ARTIGO (ABNT):}

SOLIMANI, Carlos Henrique; SIMÃO FILHO, ADALBERTO. A função social da empresa - o capitalismo humanista e a eticidade na busca da justiça social. Revista Eletrônica do Curso de Direito da UFSM, Santa Maria, RS, v. 12, n. 3, p. 990-1021, dez. 2017. ISSN 1981-3694. Disponível em: <https://periodicos.ufsm.br/revistadireito/article/view/27774>. Acesso em: dia mês. ano. doi:http://dx.doi.org/10.5902/1981369427774. 